Transactions of the Royal Asiatic Society of Great Britain and Ireland http://journals.cambridge.org/TRA

Additional services for Transactions of the Royal Asiatic Society of Great Britain and Ireland:

Email alerts: Click here

Subscriptions: Click here

Commercial reprints: Click here

\title{
XVII. Remarks on certain Sculptures in the Cave Temples of Ellora
}

James Tod

Transactions of the Royal Asiatic Society of Great Britain and Ireland / Volume 2 / Issue 01 / March 1830, pp 328 - 339
DOI: 10.1017//S0950473700001439, Published online: 19 November 2009

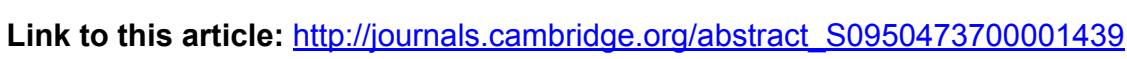

How to cite this article:
James Tod (1830). XVIII. Remarks on certain Sculptures in the Cave Temples of Ellora. Transactions of the Royal Asiatic Society of Great Britain and Ireland, 2, pp 328-339 doi:10.1017/S0950473700001439

Request Permissions : Click here 
XVII. Remarks on certain Sculptures in the Cave Temples of Ellora. By Lieut.-Colonel JAMES ToD, M.R.A.S.

Read Dec. 6, 1828.

Ir being deemed desirable that some explanation should accompany the interesting drawings, particularized in the preceding article on ancient Hindu sculptures from the Cave Temples of Ellora, made by Captain Grindlay, I hasten to fulfil the wishes of the council.

There are two modes by which they might receive illustration : one, supposing them to contain an astronomical allusion, as suggested by Dr. B. G. Babington; the other, from an allegory in the Hindu theogonies. A knowledge of the relative position of these sculptures in the Cave Temple would materially influence my decision on this point, as regards the two plates to which I shall chiefly confine my observations, viz. one, (No. 1) which I desiguate "The Fable of Dacsha Prajapáti, or Máhádéva, Dacsha, and Nanda ;" the other (No. 2) Víra-Bhadra." If these sculptures are contiguous to each other in the cave, then I have no doubt they represent the fable of the sacrifice of SATI, the consort of MÁHÁdÉ the giant Víra-Bhadra, to revenge her death by that of Dacsha : though even this allegory may possibly conceal an astronomical period.

Let us first pay due attention to Dr. Babington's suggestion, that the central figure with a bird " may represent the planet MARs (Carticeya) with his peacock, or Mercury (Búddha) with his eagle, or Saturn (Sani) with his raven; and that the personage placed between the two signs of the Zodiac, Mésha or the Ram and Vrishabha the Bull, may have allusion to some particular position of the heavens."

We bave a right to assume that the cave-worship of the Hindus had the same origin as among the ancient Persians, the Egyptians, and the Greeks, and that these caves were consecrated to rites whose bases were astronomical; and it is fair to infer that this worship originated amongst the Hindús, not confined to India proper, but from remote Scythia, embracing the caves 


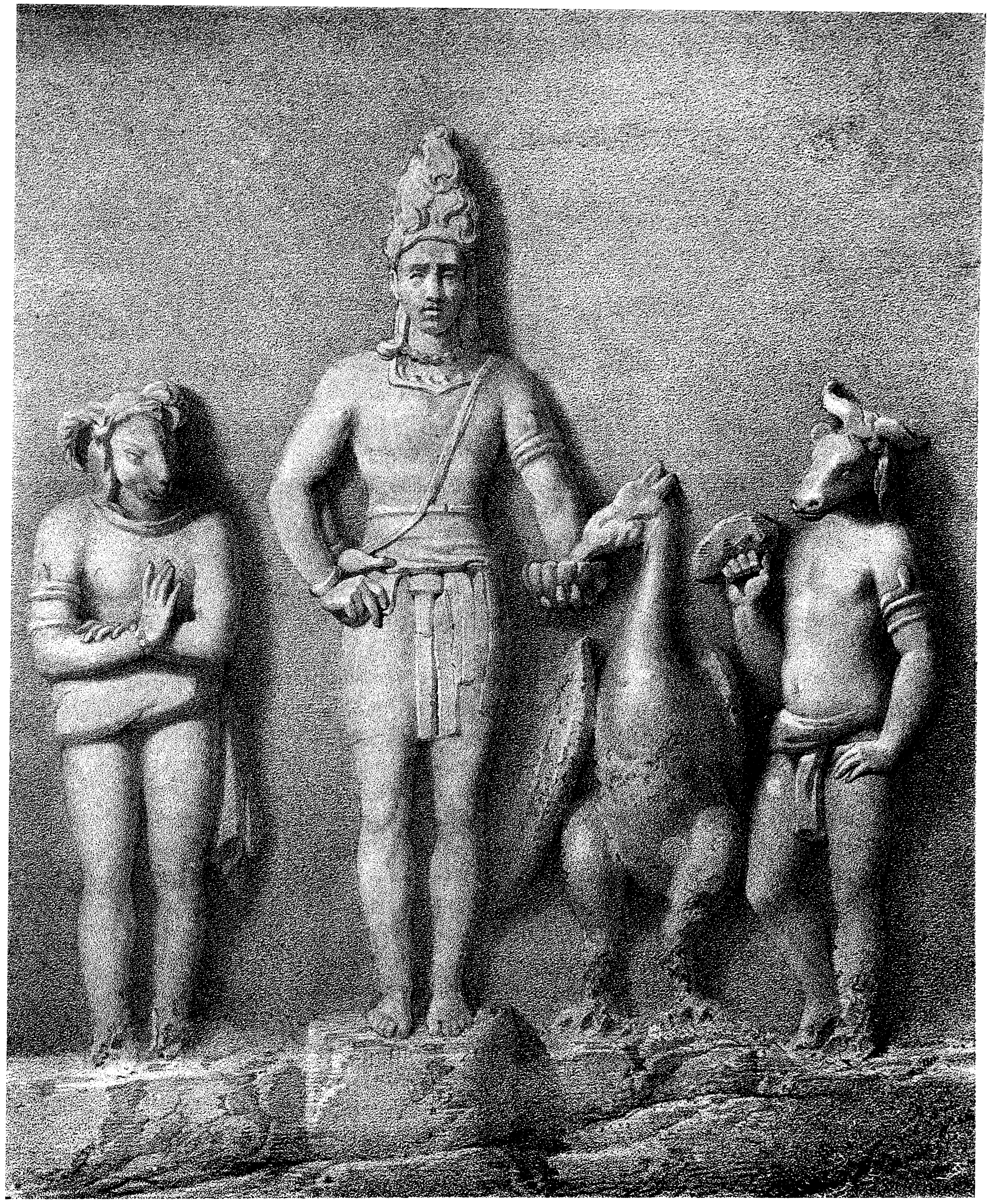

MAHADEVA, DACSHA ANG VANDA,

L.Jin she itithot 


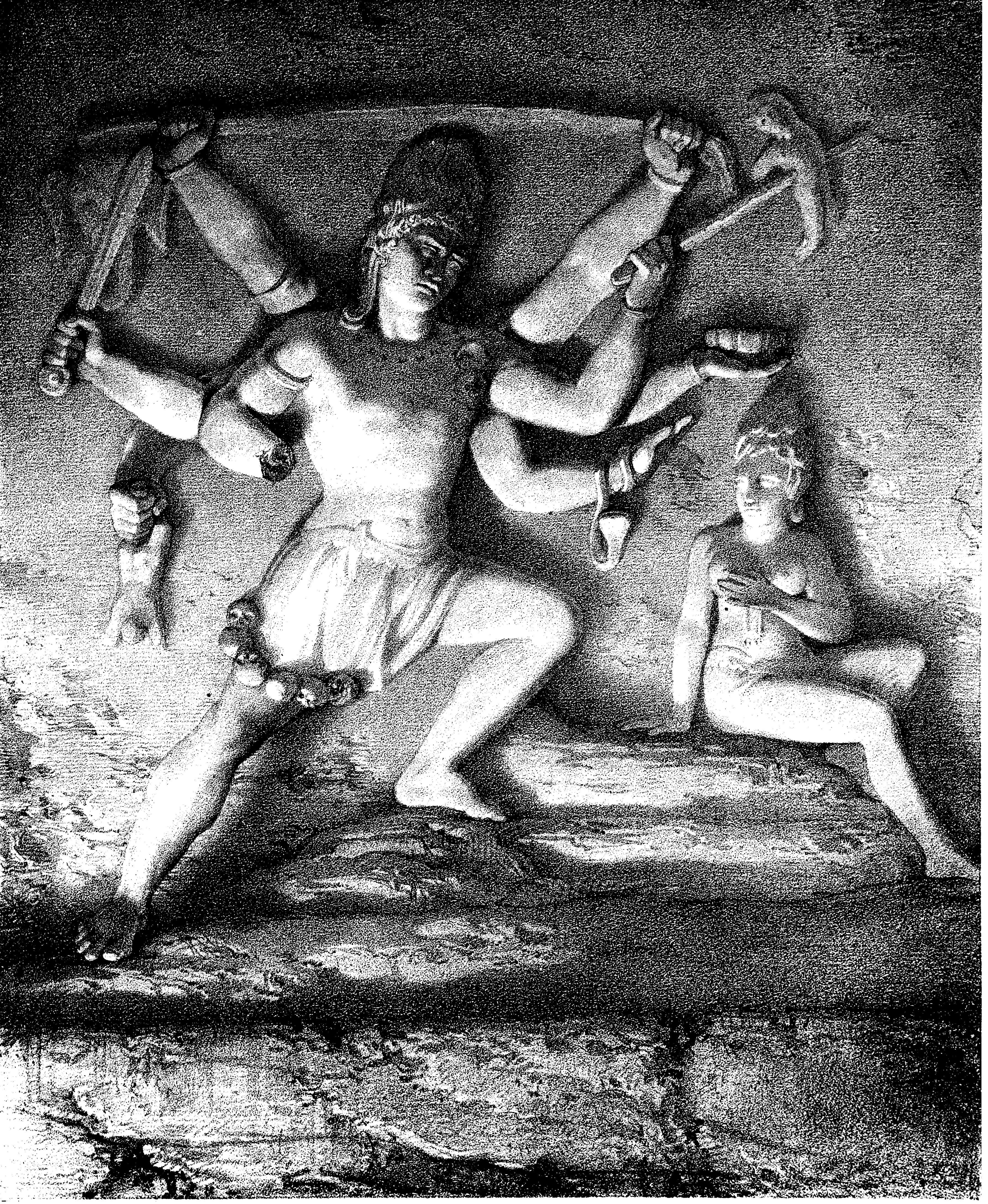




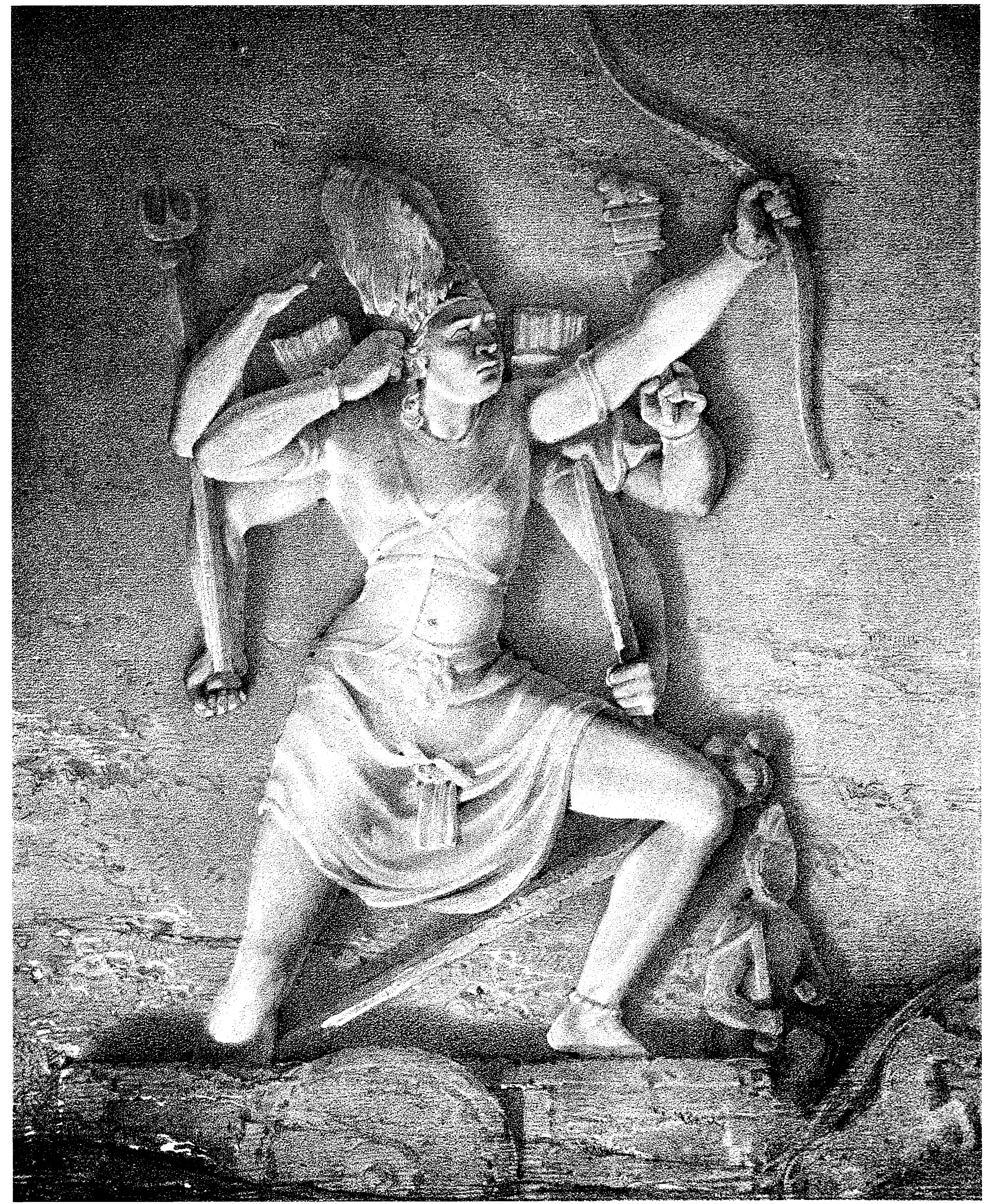

Goblet del

$$
J \breve{A} Y \breve{A} D-R A T^{\top} H \cdot A H
$$

cets Sculptured fioure in the Cave Temple of Yleiglas at Gitional.

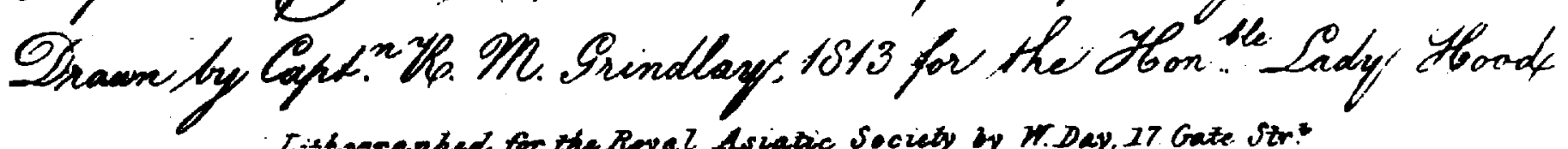



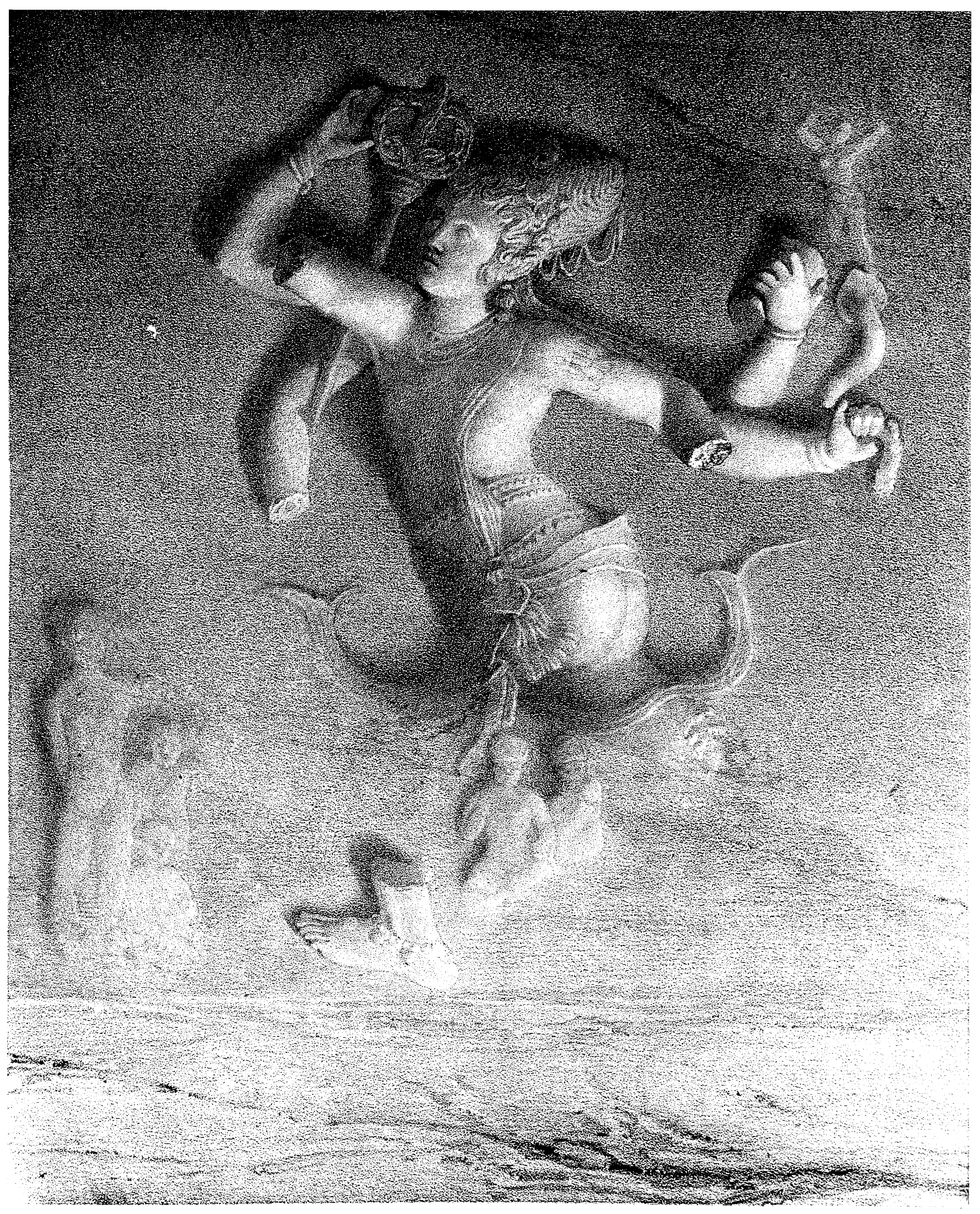
of Bamian, of Jalindra, of Gaya, of Gwalior, of Dhumrár, of Ellora, and of Elephanta. "Zoronster" (says Volney* quoting Eusebius) "was the first who, having fixed upon a cavern pleasantly situated in the mountains adjacent to Persia, formed the idea of consecrating it to Mithra (the Sun), the creator and father of all things; and having made in this cavern several geometrical divisions representing the seasons and the elements, he imitated on a small scale the order and disposition of the universe by Mithra. In these caves they celebrated mysteries, which consisted in imitating the motion of the stars, the planets, and the heavens. The initiated took the names of constellations and assumed the figures of animals. One was a lion, another a raven, and a third a ram. Hence the use of masks in the first representation of the drama; of this nature were the mysteries of Ceres." But Volney will not allow Zoroaster the honour of the invention, which he says is due to the Egyptians, of which the caverns of Thebes, full of similar pictures, afford proof.

There is a powerful analogy, both architectural and mythological, between the cave temples of Ellora and Elephanta, and Elephantine in Egypt, where certain emblematic figures appear to have the same character as those under discussion. "At Elephantine (says Volney, still quoting Eusebius) they worshipped the figure of a man in a sitting posture, painted blue, having the head of a ram and the horns of a goat which encompassed a disc: all of which represented the sun's and moon's conjunction in the sign of the ram : the blue colour denoting the power of the moon at the period of junction to raise water into clouds."

I have little doubt that the central figure is MÁÁDÉ(A, the creative power: and that he sometimes represents the solar deity, we have the best proof in seeing his monolithic emblem in the sun-temples of the ancient sun-worshippers (SAURAS, the Eúpóv of Strabo) of Saurashtra, where he is called Bál-Náth, Bál-césár, † Bál-púra, Máhádéva. As emblematic of the sun, and placed between the celestial signs Aries and Taurus, which these ram-headed and bull-headed figures represent, MÁHÁDÉva may designate the position of the sun in the Zodiac when these sculptures were executed. I shall leave to others the task of calculating the precession of the equinoxes,

* Vide "Ruins of Empires."

f In this word we should find the origin of the Persian crest, the Lion and Sun; Buil being the type of the sun, as in Bálbec (the sun-idol) of Syria, and Césír a lion.

VOL. II. 
so as to elicit the period, if such is meant to be designated. Volney says, the vernal equinox coincided with the first degree of Aries 2504 years, and with the first degree of Taurus 4619 years, before Christ.

The Egyptians supposed the Sun to assume the forms of the animals represented in the zodiac; and such is not improbably the origin of the Hindú Avataras,* an idea supported by Volney, who says: "The eagle of VIsHnú is but one of thethousand emblems of the sun, and his incarnations in a fish, boar, lion, and turtle, nothing more than the metamorphosis of the same star, which, passing successively through the signs of the twelve animals, was supposed to assume these forms."

We will now quit this speculation and proceed to the legend of the sacrifice of SÁtr and metamorphosis of Dacsha. I give it on the authority of Chand, the last of the great bards of India, who has incorporated numerous episodes from ancient mythologies.

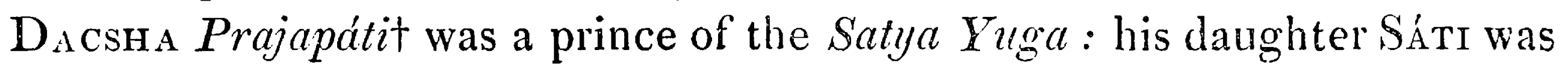
married to MÁHÁDÉva, who having offended his father-in-law, he chose to omit inviting him to attend a grand sacrifice, at which all the gods and demons (Dyte) were present. SÁtr, from the summit of Kailás beholding the assemblage, requested permission to repair thither. Síva (Máhádéva) expostulated on the indelicacy of proceeding to her father's abode uninvited; but yielded to her earnest desire, giving her his own charger $\mathrm{N}$ :NDA (Taumus), on which she joined the assembly. But her family paid the consori of Síva no attention, and portions of the sacred food were placed before the whole, absent and present, excepting only her lord. Anger so excited the faithful Sáti at this disrespect to Siva, that fire issued from her body, and she was consumed in the self-created flame. $\neq$ The infuriated $\mathrm{N}_{A N D A}$ destroyed the sacrifice, and returning to Kailás, related to MÁnÁDéva the death of his spouse. In affliction MÁHÁDéva cut off his lock $\$\left(j u t^{\prime} h a\right)$ and threw it on the earth, from which the giant Víra-BHADRA was born, who revenged the deati of Síti by the decollation of Dacsha. The gods and demons who had assembled to partake of the hospitable rites, implored of MAHÁDÉvall that

\footnotetext{
* It may be objected to this, that there are not so many Arclarcts as zodiacal signs.

+ PRAJA-PA'TI, lord of creatures.

5 'This is the origin of the immolation of females, and of the term sati (vulg. suttec).

$\xi$ In all ages, cutting off the lock appears to have been a sign of grief.

Here we see the junction of the powers of life and deatlr
} 
he would restore Dacsia to life. The father of the gods cut off the head of a goat, which he placed on the headless body of DACSHA, who instantly started up and begran to bleat like a guat, at which MÁHÁdéva was delighted and laughed immoderately ; commanding, to commemorate the event, that his votaries should bleat like a goat.**

In this legend we have all the characters necessary to explain these two fragments of antique sculpture; MÁHÁDÉva, the tauriform NANDA, and the goat-headed Dicsha. The bird which MÁnádéva feeds out of his cup, $†$ formed of a human skull, is probably the Sarus, $\ddagger$ sacred to him, and emblematic of conjugal affection,-consequently alluding to the recent sacrifice of Sátr.

In the compartment representing Víra-Bhadra, where a naked female figure is in the distance, we probably have allusion to the regeneration of the faithful SÁti (a story precisely the counterpart of that of ATYs and Cybele), who again appeared, and was wedded to Síva, as the fascinating mountain-nymph MérA, daughter of Hemachil.

This curious fable of the origin of the Hindu Pan, or Dacsha Praja. piati, has considerable affinity to the Priapus of the Greeks and Romans, even in name, and still more to what Herodotus relates of the Theban Jupiten, to whom throughout the Mendesian territory goats were sacred, and sheep sacrificed; and it will strike the Orientalist as a singular coincidence, that the word (mendes) from which this Egyptian Jupiter was designated (from rams being offered to him) should be Sanscrit, in which language mendá is ram. Herodotus thus explains its origin:§ "Jupiter cut off the head of a ram, and covering himself with the skin, shewed him-

* This is accordingly done, the cheeks are inflated, and beaten by the hands (gál bajuôná) to resemble the bleating of a goat.

$\uparrow$ Termed in the dialects cupra, and with which, as the God of war (Hur), he drinks the blood of the slain, in which he is exactly the Scandinavian Thor.

$\ddagger$ The Phenicopteros. These birds are always in pairs, and afford continual metaphors to the Hindu poet when describing domestic affection.

$\S$ Herodotus says, Mendes is alike the name of Pan and a Groat. Méndi is a ram in Sanscrit. and the ram-headed divinity in the caves of Ellora is termed Ménd-íswara, or RAM-God. The statue of Priapus was degraded into the scare-crow Terminus, as a land-mark, or territorial bcundary, by the Romans. In Rajpútana we have the ass depicted on boundary-stones: and the gadha-ghal to whosoever removes the land-mark, has a penal allusion, probably equally obscene with that of the god Terminus, of the Romans. 
self in that form to Hercules. Hence the Egyptians represent the statue of Jupiter with the head of a ram; and in the annual festival they kill a ram, and placing its skin on the image of the god, they introduce before it a figure of Hercules: the assembly afterwards beat the ram."-Euterpe. 42.

Chand the bard introduces the birth of Víra-Bhadra from the lock of Siva's hair, quite incidentally, but with great poetic skill; and as it affords, at the same time, an bistoric record of some moment, I may be excused introducing it to enliven a dull mythological speculation.

To the last great struggle which the Hindu emperor of Dehli maintained against the arms of Islám, we owe this legend. The Chohan king PrithIRÁJÁ preparing to repel the invasion of ShaHBUDín, assembles all his forces at the Chogán or champ de Mars, on a plain beyond the walls of the capital, where he takes a muster of his vassals. The ceremony is converted into a day of rejoicing, on the emperor having released from confinement, at the desire of his brother-in-law SAMARSI of Chitore, a celebrated leader called Chaond-RaÉ, who is distinguished both by the Hindu and Mahomedan writers for his conspicuous gallantry in the grand and final battle fought for Rajpút independence on the banks of the Caggar.

ChaOnd-RaÉ Dahima was lord of Biana, which house produced three of the one hundred and eight great vassal cliefs or Samants of Pritht-Raja. Besides the honours his gallantry had obtained him for the reduction of Tutta and Bamanwási in the valley of the Indus, his consequence was increased by the heir-apparent of Dehli, prince RaINasi, being his sister's child. But all his services were forgotten on his putting to death $\mathrm{H}_{\mathrm{AR} \text {-SÉN- }}$ GÁr,* the favourite elephant of his sovereign, and though the act was in self-defence, his limbs were dishonoured with fetters: a proceeding which, with other follies consequent to the enlévement of the princess of Canouj, had very nearly produced the deposal of Prithi-R $\mathrm{R}_{A} \mathrm{~J}_{\Lambda}$, which proposition was formally discussed in a convention of the chief citizens of Dehli, in which even the speeches of the leading men are preserved by the Bard. The conciliation and liberation of CHAOND-RAÉ prevented this, and the elevation of RaINASI.

The Bard describes the chivalry of the Chohan performing their evolutions, while the instruments of music, the martial Nákárás and trumpets made the welkin ring: but in the midst of this clangor and mutual greeting, 
the imperial band, which was placed on a mass of rock over a cavern, was disconcerted by a tremulous motion of the rock, followed by its dislocation and their precipitation into the cavern. All assembled round the cave, indulging in speculation on the cause ; which, while one attributed it to an earthquake, and another " to the writhing of SeHÉsNaGA,"* a third discovered in a huge monster lying in a state of torpor. Afraid to approach, they entangled him in coils of rope, and dragged him to light; when, having at length succeeded in awakening him, they desire the prophetic Bard (Chand Trí-cála) to interrogate him, and after a description of the giant which casts into shade all that was ever written on these sons of Ceelus and Terra, + the following dialogue ensues.

Chand.- "Who art thou? whence, and who thy parents? why make this thy dwelling place?"

"When at the sacrifice of Dachsa Prajapati, Sáti was consumed in the self-kindled flame and NANDA destroyed the sacrifice, dread seized the three worlds; Kailas $\ddagger$ shook, Kampila trembled; Gods, demons, and men were struck with affright at the work of destruction caused by the infuriate Nanda. At the loss of Sátr, Máhádéva cut off his jut'ha and threw it on the earth. From this lock ( $j u t^{\prime} h a$ ) I had my birth. My name VíraBhadra, my father` Trípúrári. In the Satya-yuga I was called Sancara; in the Trétu-yuga, Bál; in the Dwápara-yuga, SEHL, when I fostered mankind and religion. Then contented I reposed in Yoginipura; and now in the Kál-yúga, my name is KáL (Time). My repose has been disturbed by the uproar of mortals. What has caused the din?"

Chand._-" Oh mighty lord, such a tumult has not been heard since INDRA fought BRETÁsúRÁ, or since RÁma destroyed the abode of RAVANA : such a din has not been heard since the battle of the Pandús, or when Jarasand'ha met the Yadavas in fight. This din is raised by the Samants of Dehli assembled to oppose the King of the north, and rejoicing for the release of the Dáhimá, Chaond-RaÉ."

* The serpent which supports the globe on its head.

+ Scripture terms the giants, Zumzumin; to which a mixed Sanscrit and Persian etymology could be given, in Jenem, birth, and Zumin, earth.

† Jupiter Olympus (Kailas), and Terra, are thus made the parents of the Dytes (Titans).

§ My father (ТАUT'н)-, the universal father; probably the Toтн of the Egyptians, ànd the Teutates of the German races.-Buddha, father of the lunar race, is likewise 'Taut'i. 
TIME is indignant at being awoke from the repose of ages, by so inadequate a cause as the approaching struggle for the empire of Hindust'han, between the Chohans and the Ghorians, and treats the bard of Bhavani with but little respect. He gives vent to his indignation in the measure of verse called a Cávita.

"These are but mortals; the Gods engaged in fight have I beheld. Between Serindra and Tarika I saw the combat: in the war of Lanka I was present: in that of Magad-désa, in the time of Mandhata: that of the lofty Duryodiana and Arjúna I witnessed. O Bard of the doubletongue, these were battles!"

Chand,- "You are a God; in the combats of Gods and Titans (Dyte) you have mingled, but those of the high-minded warriors of the Chohan are also worth beholding. When their arms ply in fight the foe survives not; their heads as they fall exclaim havac, the standing trunk tranching the air, and from the blood fresh warriors rise and renew the fight. Do you, oh VíRA, accompany our warriors, and with them dance a moment in the red field of slaughter. The war of Gods and Demons, even that of the Mákibháráta of old, was not more glorious than this; nor amongst them all was there the equal of the son of Somesa."

"Víra-Bhadr.s smiled on the bard as he said " The battles I have seen with the mighty swords of old, awoke from his meditations the father of creation: nay, the chaplet dropped from his hands. Such were they, that the strong in heart wished for distance. Oh mortal, let thy words resemble thy condition, and talk not as though thou wert exalted as myself. I saw SRI Crishna in the fight with Durxodhana. Even of his immortality I had doubts; but thy words are incredible as if thou hadst said Súméru had been moved. These eyes beheld the war between $K_{A L I}$ and the Demons : the deeds of these mortals I regard as a dream."

"Víra Bhadra became warm: his eyes glared with rage. Oh bard insignificant, lower your speech. To awake me to see your conflict! tine herges of Duryódhana alone dared to do this!" As he spoke volcanic flames issued from his throat; the three worlds shook. "No battle equalled that of DuRYódhaxa; nor would I term what mortals can perform a batte. Mimic not, therefore, your superiors; but from my mouth listen to the fight of Duryódinana."

Víra-Bhadra (or Time) proceeds to relate to the Propletic Seer 'Tri-cí the events of the great international war amongst the Y'idavas, which forms 
one of the many beautiful episodes of the Rajput Homer, extracted from the ancient historical poems of the martial races, as the Máhábhárat, Rámáyúna, \&c. \&c. As I have already given the passage in a paper printed in the Transactions of the Société Asiatique of Paris, I shall refer the reader to it.*

Víra-Bhadra having related the grand battle between the Cuírús and Pándús, in turn listens to Chand, who entertains him with a biographical sketch of all the great leaders (Sámantas) assembled in the cause of Rajpút independence, and at the same time gives Víra-Bhadra a specimen of the prophetic power which gave him the title of Tri-cal, or ' cognoscent of the past, present, and future,' by revealing the events which were to follow that battle, in which he was overheard by his sovereign Prithi-raja. A grand council ensues, in which the plan of the campaign is debated, when each chieftain delivers his sentiments in an oration. Chand concludes with an invocation to Time $\left(\mathrm{K}_{\mathrm{AL}}\right)$.

\section{3d. JAYAD-RAT'HA.}

On this Charioteer, or chariot of Victory, represented by Síva, I have nothing to say. Síva, it is suggested, has borrowed the car of Súrya (the Sun) to bear him to battle; but if this were the intent, where is SAPTÁswÁ, the seven-headed horse of the Sun?

\section{4ith. Bhairava.}

Bhairava, or Bhyrú, has an important part assigned to him in the dramatis personce of the field of battle, on which occasion he represents the god of war. The rites of BhaIRAva are accordingly of a terrific description, nor can he be propitiated but by blood-offerings. There are two Bhairavas, Gorá and Kálá, or the fair and black. They are the twin sons of the terrific goddess KálicA, the Cybele of the Rajpúts, and are her standardbearers in the field of slaughter. Gorá, or the fair BhaIrava, is seldom mentioned, and the devotions of the Rajpút are generally to his sable brother, who is also called Bajranga, or of thunder-bolt frame. The dog, which is probably the only animal excluded from the honours of deification in the crowded pantheon of the Hindús, is sacred to Bhairava, and is his

\footnotetext{
* See article "De l'origine $A$ siatique de quelques-unes des anciennes Tribús de l'Europe źtablies sur les rivages de la mer Baltique,” \&c. \&c. Journal Asiatique, No. 50, Mai 18?7.
} 
companion in the field of battle ${ }^{*}$ and he is sculptured riding on a dog, with the martial horn called Napairi in one hand, and the Damru, or small drum, with which he incites the courage of the combatants, in the other. The standard of this the elder son of the god of battle, is often described by the bard as being "of the colour of the rain-cloud," or a field sable, on which a white horse passant is delineated.

On a former occassion, + I gave from the great bard of the martial Rajpúts, a slight sketch of the machinery of a field of battle, in which CHAnd, like Homer, brings the celestials to view, and often to mix with the fight. But Chand's mythology takes a wider range than Homer's, and we must have recourse to the Scald of Scandinavia for a parallel to much of his imagery; forthough Chand makes Kailasa shake, as Homer did Olympus with the anger of Jíva PITRI, the Greek was too refined to make the father of the gods quaff

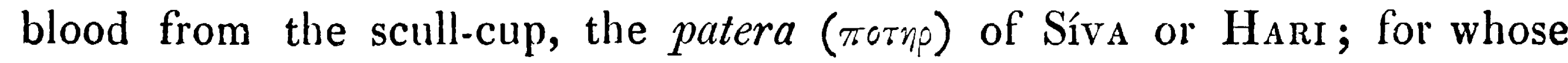
counterpart we must have reference to the THor of the Northman, as well as for the sisters of our Apsaras and Palcharas, the Valk rries $\ddagger$ of northern mythology.

In every field of battle, either Síva, or his consort, the terrific MATA, leads the war. She is on her lion, armed with the trident, preceded by her standard-bearing sons, the Bhairavas, and followed by " the fatal sisters" the sixty-four Yoginis, with clouds of inferior powers all of female personifcation, and each holding a patera of the scull. Another extract from CHAND may better illustrate this, taken from one of the most interesting of the sixty-nine cantos of the bard, entitled "the Battle of Canouj, or the Vow of Sunjogta."S I select a passage to shew that the bards of the Rajpúts, like those of Scandinavia, incited the warriors to deeds of glory by their example as well as by their poesy.

* The battle shouts of the Rajpút warrior are "Hari-Hari (the common epithet of Síva as god of war)," and " havac, havac." We might suppose the "immortal bard" had been reading CHAND, the HOMER of the Rajpúts, when he exclaims

" Cry havoc, and let slip the dogs of war."

Havoc is from the Cimbric or Welsh "hafog," meaning slaughter.

+ See Transactions of the Royal Asiatic Society, vol. i, p. 151.

$\ddagger$ See Transactions of the Royal Asiatic Society, vol. i, p. 150.

$\S$ If these and the preceding extracts from the bard CHAND should excite an interest in the Society, it would be an inducement to me to give a few cantos, preceded by a biographical introduction on the life of his hero, the last emperor of the Hindús, as papers for the Transactions of the Society. 
The Chohán prince of Dehli had carried off the Princess of Canouj. Her father, Jychund, at the head of all his forces, pursues, and the period of time when the bard CH $\Lambda$ ND engages is on the fourth day's fight, when they had almost reached the ferry of the Ganges. By this time Prithi-Raja had lost nearly three-fourths of his heroes, and he is about placing his bride, Sunjogta (who had hitherto remained on the same horse with himself), on a separate steed. Although night, there was no cessation of the fight, during the retreat from Canouj to Dehli.

"Night came: the beam of moon arose. The lord of men descended from his steed, and placed Sunjogta on another. The blood-stained arrows Hy: one pierced the casque of the Chohan. Then did the bard demand to wield the sword; but his prince exclaimed, 'Strong are our swords, oh bard, leave thou the fight, that we may live in song.'-' To sing your renown, oh lord, I leave Julhun, my son: for me, I make offering of my head to Mahndeo.'

"As he spoke he gave his steed the rein: on his countenance shone the light of honour. The InDRa of song dashed into the throng of fight, like the moon* athwart the constellations. His steed Keshore, the gift of his lord, fit to be yoked to the chariot of the sun, of the blood of Irak, t like a wave of the sea, his ear the lance's point, his eye soft as that of the fair, his mane like the rippling wave: from the bucklers of the slain his hoof struck fire as he bore the bard to battle. Where'er his sword fell, the Yoginis filled their cups with the blood of the nortimen. The gods shouted applause. Covered with wounds was Keshore, but the mountain-born $\neq$ preserved her worshipper. The Apsaras sung his praise, the Palcharas $\leqq$ feasted in the track of his sword. Applause $\|$ to the bard! He rejoined his lord on foot; his steed lay in the field.

* Here we lose the force of the original, for CHAND (the Bard) compares the rapidity of his own movements to those of Chandra (the moon) passing over the constellations : one of the many jeux de mots in which our poet indulges.

+ A Persian province renowed for its breed of horses.

† Parvatí, one of the names of the Indian Minerva.

Palchara is from pala 'Alesh,' and charma ' to feed on.' The ralkyrie of Scandina' ina mythology, is a being oetween the Apsara and Palchara; neither so etherial as the first, nor s.: material as the latter.

II The warlite bards of Ind, like the scalds and poctic heross of Scandinavia, possessed noit. of the false shame which prevented their lauding thenselves on it occasion. CinlND is a cniispicuous example of this, never omiting an oppcrtunity of culogizing his own valour.

VoL, II. 
"The battle raged. Steel met steel; the mace resounds on the helm; the heroes are inebriated with the war-song; bucklers are broken in pieces. The gods convene above. Never, say they, such deeds did mortals per. form : they fight on mountains of slain, o'er whose sides descend rivers of blood.

"Then did Utritar seize his trident. The Yoginis in his train, he rushed into the field. Each held the patera to drink the blood of the slain. $\mathrm{M}_{\mathrm{A}}$ HADEO followed his favourite to obtain a gem for his necklace.* In the lake of battle Utтitar cut down the lotus; his trident broke the dam which kept in its waters. MAnaDeo filled his chaplet: the Dévis glutted with blood. Jesswunt Rahtore bowed to his lord as he opposed the hero; but with a laugh Utтitai threw his heal at the feet of MAHadeo. Once more the Mirs of the north t engaged; fiseh heroes of Cinouj replaced the slain. Rемвна and the heavenly fair descended. Utritai was their choice, but the Urveisis $\ddagger$ quarrelled for the hero: they agreed to share him amongst them. Thrice the hero broke the circle of fight. When the wa:shell reached his ear, his head touched heaven: the host of Canouj fled before him; the Yoginis exclaimed, 'Victory to Utritai!' while each host called aloud, 'Renown to the lord of the trident!' The Apsaras hovered o'er the hero, each eagerly struggled; but nor RembHa nor Apsara was destined; Gunga $\oint$ herself received her son in her embrace: the wave closed o'er the form of Utritai.

"The Gandarvall took flight for the regions above: to the god of the

The Edda affords affords many specimens of the same character. In the following runic verses, a northern hero is introduced boasting of himself:

"I am master of nine accomplishments. I play well at chess; I know how to engrave runic letters; I am apt at my book, and know how to handle the tools of the smith; I traverse the snow in skaits of wood; I excel in shooting with the bow, and in managing the oar ; I sing to the harp and compose verses."

Chand gives his hero, Pritir RAJA, thirty-two accomplishments, besides seventy-two graces of a minor description!

* By this metaphor the Bard prepares us for the death of the hero.

i A title applied to the Syuds, of which tribe was the prophet Mahommed.

I A title of the Apsaras, implying "dwellers on the breast" (urra).

$\$$ The virtues of the Ganges as a lustral stream are well known. To dir on its banks is certain beatitude, and the ashes of ereat men are conveyed many hundred miles to ho consigned to itc waters.

ii A celestial chorister. 
Lieut.-Colonel ToD on Sculphures in the Temnles of Ellarw.

firmament he related the deeds of Utrrta. INDra prepared lis car io view the fight. Crowds of Apsaras* filled the valt of herren, each ascoming with the heroes of their choice.

"As the mountain torrent bursting its bounds expands o'er the plain, so flowed the current of blood. Gunga's wave was crimsoned with the slain, borses and riders were borne down her flood. In the array of war UtтiтaI was of victory the pillar; when received into Gunga's embrace, again did the foe encompass Dehli's lord."

* "APSARA" is one of the celestial messengers who convey the heroes that fall in battle to the heaven allotted to them, and attend on them there. They have all the characteristics of "Odin's maids of war," though the Apsar $\Lambda$ is of more etherial mould. RembHA, the Hindu Venus, is queen of the Apsaras, which word has precisely the same etymology as Aphrodite, one of the names of Venus, because born from the froth of the sea, viz. Al, 'water,' and sira ' the essence, cream, or froth.'

I shall some day pursue these analogies in points of Grecion and Hindu mythology, hitherto unnoticed. 